\title{
PREFERENCJE OSÓB Z DYSFUNKCJĄ WZROKU W ZAKRESIE KORZYSTANIA Z INFORMACYJNO- -KOMUNIKACYJNYCH TECHNOLOGII WSPOMAGAJĄCYCH
}

Streszczenie: W artykule podjęto zagadnienie preferencji osób z dysfunkcją wzroku w zakresie korzystania z informacyjno-komunikacyjnych technologii wspomagających. Osoby niewidome i słabowidzące dzięki wykorzystaniu technologii wspomagających kompensują brak lub ograniczenie informacji dostarczanych kanałem wzrokowym, koniecznych do zdobywania wiedzy, komunikowania się i mobilności. W artykule omówiono możliwości i bariery wykorzystania technologii wspomagających przez osoby z dysfunkcją wzroku ze szczególnym uwzględnieniem czynników społecznych warunkujących preferencje wyboru sprzętu i oprogramowania - na podstawie badań (głównie zagranicznych) podejmujących te kwestie. Przegląd i analiza danych empirycznych posłużyły do sformułowania wniosków istotnych dla praktyki tyflopedagogicznej.

Słowa kluczowe: preferencje, niewidzenie, niepełnosprawność wzroku, technologie wspomagające, system brajlowski, czynniki społeczne.

\section{Wstęp}

Technologie wspomagające służą do wyrównywania ograniczeń funkcjonowania osób z niepełną sprawnością, wzmacniając ich autonomię oraz niezależność i oddziałując na sferę działalności praktycznej, edukacyjnej, zawodowej i społecznej. Osoby niewidome i słabowidzące dzięki informacyjno-komunikacyjnym technologiom wspomagającym mają możliwość odbierania, wysyłania, tworzenia, przetwarzania i gromadzenia informacji w różnych formatach. Niewidomi kompensują w ten sposób niemożność korzystania ze wzrokowych źródeł informacji. W związku z dynamicznym rozwojem technologii mogą mieć dostęp do danych drogą pozawzrokową w sposób coraz bardziej zróżnicowany, zindywidualizowany i wyspecjalizowany dzięki monitorom brajlowskim, notatnikom brajlowskim, syntezatorom mowy, programom odczytu ekranu, drukarkom brajlowskim, nadajnikom GPS, czytnikom kodów i etykiet, czytnikom kolorów oraz oprogramowaniu służącemu do rozpoznawania druku i konwersji 
tekstów w druku płaskim do formatu brajlowskiego lub audio. Osoby słabowidzące natomiast korzystają z danych słuchowych lub wzrokowych (te zaś dzięki systemom powiększania i zmiany cech wizualnych wyświetlanych obiektów, takich jak m.in. barwa i kontrast, np. zastosowanych w lupach elektronicznych, powiększalnikach telewizyjnych czy urządzeniach mobilnych mogą być przez nich lepiej odbierane).

$\mathrm{W}$ środowisku osób z dysfunkcją wzroku pojawia się teza o „wielkim technologicznym skoku niewidomych". W literaturze tyflologicznej i popularnonaukowej przede wszystkim prezentowane są nowe rozwiązania z zakresu technologii wspomagającej, jednak ich omawianie i popularyzowanie nie pozwala wnioskować o skali faktycznego wykorzystywania oraz o perspektywach, z jakich użytkownicy niewidomi i słabowidzący oceniają ich funkcjonalność w swoim codziennym życiu.

Perspektywa użytkowników technologii wspomagających jest ważnym wskaźnikiem ukierunkowującym proces tworzenia i modyfikowania narzędzi. Powinna mieć również znaczenie dla metodyki nauczania korzystania ze sprzętu i oprogramowania wspierającego, aby przebiegało to sprawnie w przypadku osób z dysfunkcją wzroku. Preferencje, czyli „przedkładanie czegoś nad cos””; „pierwszeństwo, przewaga, górowanie czegoś nad czymś” (Sobol 2002), „sposób zachowania ludzi, gdy porównują alternatywne sposoby wydatkowania środków" (Burda, Wyplosz 2000, s. 700) wiążą się z poczuciem przydatności (satysfakcji czerpanej z konsumpcji - wybierane są oferty bardziej użyteczne od mniej użytecznych), w sytuacji dysponowania pełną informacją na temat możliwych do wykorzystania produktów oraz posiadania umiejętności oceny ich użyteczności w stosunku do swoich potrzeb (Zawadzka 2002). Ważnym aksjomatem teorii preferencji jest zupełność - założenie, że dwa koszyki dóbr mogą być porównywalne (Varian 2005).

W nawiązaniu do wymienionych powyżej tez kontekstowych, celem artykułu uczyniono analizę wyników badań (głównie zagranicznych, ze względu na niedostatek badań krajowych), eksplorujących preferencje osób z dysfunkcją wzroku w zakresie korzystania z technologii wspomagających i próbę wywiedzenia z nich wniosków istotnych dla praktyki pedagogicznej. Wartością dodaną przeglądu badań będzie również ukazanie ich procedur i kontekstu kulturowego, co może być cenną płaszczyzną przy porównaniu wyników badań lokalnych.

\section{Użytkowanie technologii wspomagającej osoby niewidome i słabowidzące w Polsce}

Osoby z dysfunkcją deklarują pozytywny stosunek do udogodnień technicznych, wskazując komputer oraz program odczytu ekranu i syntezator mowy

\footnotetext{
${ }^{1}$ Na przykład tematem przewodnim XII edycji konferencji „Reha for the Blind Poland” (2014) corocznego największego spotkania środowiska osób niewidomych, słabowidzących oraz ich bliskich, organizowanego przez Fundację Szansa dla Niewidomych, było „25 lat polskich przemian. Wielki technologiczny skok niewidomych - od izolacji do integracji”.
} 
(warunkujące korzystanie z komputera) jako znacznie ułatwiające życie (Łukowski 2008). Użytkownicy potrafią samodzielnie obsługiwać skaner, syntezator mowy, drukarkę czarnodrukową (wskazania na poziomie $80-98$ proc.). Inne urządzenia, tj. notatnik mówiący, notatnik brajlowski, monitor brajlowski czy drukarka brajlowska wskazywane są rzadziej (12-30 proc.) (Walter 2007). Polscy użytkownicy w zdecydowanej większości preferują urządzenia wykorzystujące kanał słuchowy (przekaz za pomocą mowy). Ma to związek z:

- dysproporcją cenową pomiędzy urządzeniami wykorzystującymi brajla a systemami audialnymi;

- nieznajomością brajla (dotyczy to osób, które utraciły wzrok w dorosłości lub w starszym wieku);

- brakiem wsparcia z zewnątrz;

- przekonaniem o złożoności technicznej i nieprzydatności narzędzi bazujących na wyświetlaczach brajlowskich.

Jeśli chodzi o użytkowanie technologii wspomagających przez dzieci i młodzież z dysfunkcją wzroku, to M. Rubin, M. Faderewski, D. Mikułowski (2015) stwierdzają na podstawie sondażu przeprowadzonego w grupie 47 uczniów (36 uczniów słabowidzących - 77 proc., 11 niewidomych), że korzystają oni z komputera i internetu, w tym 64 proc. $z$ nich korzysta codziennie (w większości uczniowie szkół ponadgimnazjalnych i gimnazjum), a 51 proc. uczestników badań na co dzień korzysta z urządzenia typu tablet czy smartfon (87 proc. tej grupy to słabowidzący). Z eksploracji E. Śmiechowskiej-Petrovskij (2016) (grupa 18 uczniów z niepełnosprawnością wzroku, jakościowe metody gromadzenia i opracowywania danych) wynika, że uczniowie starszych klas szkoły podstawowej, z gimnazjum i ze szkół ponadgimnazjalnych, w większości posługują się telefonami (smartfonami) (telefonowanie, wysyłanie i odbieranie SMS-ów, granie w gry komputerowe, słuchanie muzyki). Ci, którzy wyżej funkcjonują wzrokowo, są entuzjastycznie nastawieni do korzystania z nowych mediów informacyjno-komunikacyjnych (gry komputerowe, korzystanie z internetu - YouTube, mediów społecznościowych - Facebook). Z kolei uczniowie o ograniczonych możliwościach wzrokowych (niewidzący, głęboko słabowidzący, zagrożeni utratą widzenia) prezentują deficyty umiejętności w pisaniu bezwzrokowym na klawiaturze komputera, nie korzystają efektywnie ze skrótów klawiszowych, a ponadto nie są sprawni w użytkowaniu programów odczytu ekranu, syntezatora mowy i monitora brajlowskiego - te umiejętności wymagają bowiem wielu ćwiczeń i wsparcia edukacyjnego.

\section{Użytkowanie technologii wspomagającej przez osoby niewidome i słabowidzące w różnych krajach świata}

Na podstawie analizy badań empirycznych dotyczących wykorzystywania informacyjno-komunikacyjnych technologii wspomagających przez osoby z dysfunkcją wzroku, prowadzonych w szczególności na gruncie amerykańskim, brytyjskim 
oraz skandynawskim ${ }^{2}$, wyłoniono kluczowe dylematy dotyczące preferencji tych osób w zakresie korzystania z technologii wspomagających, które zostaną zaprezentowane poniżej. Istotne jest jednak ukazanie aspektów metodologicznych realizowanych badań, które mają znaczenie dla właściwej interpretacji danych:

- badania prowadzone w obszarze wykorzystania technologii wspomagającej przez osoby z dysfunkcją wzroku mają na ogół charakter idiograficzny;

- ukierunkowane są na nakreślenie obrazu indywidualnych doświadczeń osób badanych i cech zjawisk dokonujących się w konkretnym miejscu i kontekście, w związku z tym uzyskane dane są wrażliwe na warunki socjoekonomiczne i kulturowe;

- praktykuje się prowadzenie dyskretnej obserwacji spontanicznych czynności codziennych użytkowników technologii oraz bezpośrednio zaplanowane wywiady, co zwiększa szansę na ustalenie preferencji rzeczywistych, a nie tylko wyrażanych;

- badane grupy są mało liczne (prowadzone są studia indywidualnych przypadków lub poddaje się badaniom grupy kilku- i kilkunastoosobowe).

\section{Mono- versus multimodalność informacyjno-komunikacyjnych technologii wspomagających}

Osoby z dysfunkcją wzroku stają przed wyborem sprzętu i oprogramowania wykorzystującego zmysł dotyku lub/i słuchu. Dylemat związany z formatem materiału: brajlowskim lub audio od wielu lat jest dyskutowany w środowisku naukowym i wśród samych osób z uszkodzeniem wzrokiem. Brajl jest systemem ekwiwalentnym względem czarnego druku, dzięki czemu możliwe jest dokładne odwzorowanie zapisów tekstowych i większości specjalistycznych treści (matematycznych, fizycznych, chemicznych, muzycznych). Pobieranie informacji wyłącznie drogą słuchową może prowadzić do wtórnego analfabetyzmu, stąd tyflopedagodzy są zgodni co do konieczności korzystania z pisma brajla przez niewidomych, zwłaszcza na wczesnym etapie edukacyjnym. Sami użytkownicy deklarują, że korzystanie z brajla jest ważne ze względu na naukę właściwej pisowni, gramatyki, interpunkcji, struktury zdania, tworzenia akapitów (D’Andrea 2012). Ponadto czytanie brajla to aktywne czytanie, umożliwiające skoncentrowanie uwagi na szczegółach i zrozumienie kontekstu treściowego (Cryer, Home 2011).

Z kolei korzystanie $\mathrm{z}$ formatów audio jest postrzegane przez użytkowników jako szybszy dostęp do informacji (D’Andrea 2012), wymagający mniejszego nakładu pracy.

Inny dylemat związany jest $\mathrm{z}$ wyborem nośnika $\mathrm{z}$ tekstem brajlowskim - książek, materiałów wydrukowanych na papierze lub korzystania z cyfrowego brajla, czyli z elektronicznych notatników i monitorów brajlowskich, na których tekst

\footnotetext{
${ }^{2}$ Wyniki wzmiankowanych badań zostały opisane w dalszych fragmentach artykułu.
} 
wyświetlany jest poprzez uwypuklenie na panelu dotykowym specjalnych bolców tworzących litery Braille’a.

Zapoznawanie się z materiałami wydrukowanymi w brajlu, zwłaszcza w postaci książek, postrzegane jest jako proces przebiegający ogólnie wolno i niekomfortowo pod względem organizacyjnym. Książki brajlowskie mają duże rozmiary, co utrudnia noszenie ich ze sobą. Podział podręcznika brajlowskiego na tomy, ze względu na jego objętość, utrudnia wyszukiwanie informacji, gdyż wymaga posłużenia się dalszą częścią publikacji. W tym kontekście technologie wykorzystujące brajla (notatniki brajlowskie) pozwalają na przechowywanie wielu plików w jednym miejscu i dają możliwość skorzystania z opcji wyszukiwania (D’Andrea 2012; Cryer, Home 2011). Niemniej materiały w brajlu papierowym są wykorzystywane przez użytkowników i postrzegane jako niezbędne w odniesieniu do nauki matematyki i przedmiotów ścisłych oraz języków obcych (niezależnie od poziomu edukacji) (D’Andrea 2012).

Z kolei brajl cyfrowy (odczytywane na linijce brajlowskiej zasoby komputerowe lub korzystanie z notatnika brajlowskiego) jest wykorzystywany najczęściej przez studentów (wersje elektroniczne podręczników i materiałów). Brajl cyfrowy jest postrzegany jako medium umożliwiające dostęp do środowiska komputerowego (D’Andrea 2012).

Wady cyfrowego brajla to wolniejsze tempo czytania niż brajla wydrukowanego i mniej relaksujący proces czytania, wynikający z niezbyt przyjaznych dotykowo właściwości wypukłych bolców tworzących litery Braille’a w notatnikach brajlowskich i na linijkach. W niektórych badaniach jednak wskazywano, że brajl cyfrowy jest czytelniejszy - punkty są wyraźniejsze niż na wydruku (Bickford, Falco 2012). Ponadto użytkownicy narzekali na trudności w zrozumieniu kontekstu i układu treści odczytywanego linearnie tekstu na monitorze brajlowskim. Pojedyncza linia brajla wyświetlana na urządzeniu nie zapewnia ergonomiczności procesu czytania. Ponadto nie pozwala na budowanie wyobrażeń przestrzennych związanych z układem strony czy rozmieszczeniem elementów względem siebie, co jest niekiedy istotne dla zrozumienia przekazu. Problemem użytkowników brajla elektronicznego jest także częsty brak kompatybilności sprzętu z dodatkowym oprogramowaniem (Cryer, Home 2011).

Wobec konkurujących ze sobą strategii dotykowych (brajl) i słuchowych (formaty audio) istotne jest określenie efektywności pozyskiwania informacji w codziennych zadaniach dzięki systemom audio i opartych na brajlu. Z badań Y. Shimomury, E. Hvannberg, H. Hafsteinssona (2010) wynika, iż przy odbieraniu i czytaniu e-maili, organizowaniu kontaktów, przetwarzaniu tekstów, wyszukiwaniu informacji i używaniu kalkulatora osoby niewidome częściej korzystają z narzędzi opartych na syntezie mowy. Porównanie doświadczeń grup wykorzystujących alternatywne sposoby pokazuje, że wykonanie tych zadań - niezależnie od obranej strategii (linijka brajlowska, synteza mowy) - było na podobnym poziomie, ale satysfakcja $\mathrm{z}$ ich wykonania była większa przy wykorzystaniu narzędzia brajlowskiego. 
Zarysowane dylematy uwypuklają się w sytuacji ograniczonego, z racji braku wiedzy lub barier finansowych, dostępu do technologii wspomagających. W gruncie rzeczy technologie oparte na mowie i alfabecie brajlowskim nie powinny być opozycyjnymi rozwiązaniami, ponieważ niespełniony jest wówczas warunek zupełności. Żadne z rozwiązań nie umożliwia osobie z dysfunkcją wzroku, zwłaszcza niewidomej, w sposób kompletny poradzenia sobie z dostępem do zróżnicowanych danych w wielorakich sytuacjach. W istocie najważniejsza dla dostępu niewidomych do informacji jest multimodalność sprzętu i oprogramowania (D’Andrea, 2012; Shinohara, Tenenberg 2009; Chan, Foss, Poisner 2009) - umożliwiająca swobodę korzystania z różnych opcji (słuchowych, dotykowych) w zależności od zadań i sytuacji. Gdy nie jest to możliwe, ważne jest by mieć wybór w zakresie doboru sprzętu do różnych potrzeb. W badaniach M. F. D’Andrea (2012) wszyscy badani wymieniali przynajmniej cztery technologie używane przez siebie: wszyscy wymieniali udźwiękowiony komputer, ponadto wybierano m.in. notatnik brajlowski, syntezator mowy, udźwiękowiony telefon czy podręczniki elektroniczne wraz ze sprzętem umożliwiającym korzystanie z nich. Zgodnie wyrażano przekonanie co do konieczności uczenia się wykorzystania różnych technologii wspomagających.

Z kolei J. O. Bickford i R. A. Falco (2012) zauważyli, że nie ma różnicy pomiędzy młodszymi użytkownikami brajla, korzystającymi z tradycyjnego wydruku i tymi, którzy korzystają z notatników brajlowskich. Jeśli w edukacji wykorzystywane będą zróżnicowane materiały - tradycyjne i alternatywne, uczniowie z łatwością będą transferować umiejętności korzystania z brajla i wykonywania edukacyjnych zadań $z$ jednego systemu na drugi.

W związku z powyższymi spostrzeżeniami, dla praktyki pedagogicznej istotna jest wczesna integracja strategii edukacyjnych opartych na nowych technologiach, wykorzystujących kanał dźwiękowy i dotykowy oraz brajla tradycyjnego i cyfrowego, a także dostęp do zróżnicowanych technik tworzenia i odbioru materiałów czytelniczych (Ferrell, Bruce, Luckner 2014).

\section{Preferencje w zakresie stopnia wyspecjalizowania technologii informacyjno-komunikacyjnych}

Współcześnie kompensowanie braków wynikających z uszkodzonego analizatora wzroku może się dokonywać nie tylko dzięki technologiom wspomagającym urządzeniom i systemom specjalistycznym, zaawansowanym technologicznie, lecz również - w skutek uniwersalnego projektowania - dzięki urządzeniom z głównego nurtu rynkowego (telefonom, laptopom, tabletom), które coraz częściej uzupełniane są o dodatkowe moduły powiększające obraz na ekranie, wyposażone są w syntezatory mowy lub w systemy rozpoznawania głosu. Urządzenia specjalistyczne są droższe, bardziej skomplikowane i wymagają zapewnienia użytkownikom niezbędnej pomocy technicznej. Jednak są lepiej dostosowane do indywidualnych potrzeb użytkowników (D’Andrea 2012). Mimo to formułowana jest teza, iż społeczne 
koszty użytkowania technologii wspomagających mogą być wyższe (w niektórych badaniach pomoce te postrzegane są w kategoriach znaczników ułomności, konstruujących negatywnie tożsamość jednostek) (Söderström, Ytterhus 2010; Ravneberg 2009; Wielandt, McKenna, Tooth, Strong 2006). Urządzenia z głównego nurtu rynkowego natomiast są tańsze, łatwiejsze w użytkowaniu i w zakresie dostępu do wsparcia technicznego, nie są jednak tak dobrze dostosowane do zindywidualizowanych potrzeb użytkowników (mimo to niektórzy z nich wolą laptop niż notatnik brajlowski). Istotną cechą tych urządzeń jest to, że nie znaczą in minus.

Należy pamiętać, że uniwersalne projektowanie, choć niesie nadzieję na pełniejsze społeczne włączenie osób mających specjalne potrzeby w zakresie pozyskiwania informacji, skoro możliwe będzie użytkowanie tych samych akcesoriów, z których wszyscy korzystają, nie jest jednak rozwiązaniem totalnym, ze względu na niejednolite potrzeby i możliwości poszczególnych osób doświadczających dysfunkcji wzroku. Uniwersalne projektowanie w zakresie technologii informacyjno-komunikacyjnych różni się od uniwersalnego projektowania przestrzeni. Nie jest możliwa optymalna konfiguracja systemów, usług informatycznych i interfejsów. Dlatego wydaje się konieczne rozwijanie zarówno technologii wspomagających, jak i komplementarnie - systemów z głównego nurtu rynkowego (Emiliani 2006), a także wyposażanie osób niepełnosprawnych wzrokowo w wiedzę i umiejętności związane z wykorzystaniem obu opcji.

\section{Czynniki społeczne istotne w wyborze informacyjno-komunikacyjnych technologii wspomagających}

Oprócz multimodalności i funkcjonalności technologii stwierdzanych na poziomie projektowym i testowym w warunkach laboratoryjnych, dla wyboru technologii wspomagających istotne znaczenie mają czynniki społeczne i cechy osobnicze niewidomych i słabowidzących użytkowników.

S. Chan, B. Foss, D. Poisner (2009) wymieniają trzy atrybuty nowych technologii, które są istotne dla użytkowników: dokładność, czyli jakość dostarczonego materiału, wygoda użytkowania (preferowany jest sprzęt ergonomiczny i łatwy w użyciu w dowolnym miejscu i czasie) oraz dyskrecja użytkowania (korzystanie z danego urządzenia nie powinno skupiać uwagi innych osób na użytkowniku narzędzi wspomagających, stąd np. wybieranie notatników brajlowskich czy ubrajlowionych zegarków, zamiast pomocy mówiących). Dla nastolatków istotne są ponadto niewielkie rozmiary urządzenia, aby było ono jak najcieńsze i najlżejsze. Użytkownicy cenią sobie nie tylko użyteczność narzędzi wspomagających, ale również ich estetykę. Nie zawsze to, co technologicznie najlepsze w warunkach laboratoryjnych, jest preferowane przez odbiorców.

A zatem ważna jest interakcja pomiędzy osobami z dysfunkcją wzroku, konkretnymi narzędziami wspomagającymi i środowiskiem zewnętrznym (Arthanat i in. 2007). Na przykład osoby niewidome chciałyby korzystać z urządzeń 
z wyświetlaczem zwykłego druku, aby dzielić się informacjami z osobami widzącymi (Chan, Foss, Poisner 2009). Z polskich badań również wynika, że istotne dla użytkowników jest przygotowywanie materiałów w zwykłym druku - dla nich niedostępnym, ale dla bliskich im osób widzących czytelnych, o czym świadczy wysoka popularność drukarek czarnodrukowych wśród osób niewidomych (Kilian, Śmiechowska-Petrovskij 2015).

\section{Koszty społeczne - technologia wspomagająca jako czynnik dewaluujący osobę z niepełnosprawnością wzroku}

W obszarze czynników społecznych ważnych dla korzystania z informacyjno-komunikacyjnych technologii wspomagających mieści się również zagadnienie społecznych kosztów związanych z ich użytkowaniem - określenie, jakie symboliczne wartości są przez osoby z niepełnosprawnością wzroku przypisywane tym narzędziom i jak wpływają na ich wykorzystywanie?

We współczesnym świecie umiejętność korzystania z technologii informacyjno-komunikacyjnych jest symbolem kompetencji, przynależności i niezależności. S. Söderström i B. Ytterhus (2010) w swoich badaniach zauważają jednak, że stosowanie technologii wspomagających przez młode osoby z dysfunkcją wzroku postrzegane jest jako symbol ograniczenia, różnicy i zależności. Ma to szczególne znaczenie dla jednostek słabowidzących, które w ambiwalentny sposób ustosunkowują się do swojej niepełnosprawności - mimo doświadczanych utrudnień w funkcjonowaniu nie deklarują, że niepełnosprawność jest elementem ich tożsamości. Chcą być postrzegane jako osoby sprawne - ma dla nich znaczenie bycie odbieranym jako „zwyczajna osoba”. W badaniach potwierdziła się teza, że technologie wspomagające są obciążone zbiorowymi kulturowymi wartościami, jak również subiektywnymi odczuciami i znaczeniami im przypisywanymi. Osoby słabowidzące odrzucały zdecydowanie technologie wspomagające (bazujące na powiększaniu obrazu). Powiększanie obrazu, np. podczas wykorzystywania komputera razem ze sprawnymi rówieśnikami, podczas grania w gry komputerowe, jest równoznaczne z postrzeganiem osoby jako mniej utalentowanego gracza. Niemniej jednak osoba taka wolałaby być postrzegana jako przyjaciel i słabszy gracz częściej, niż jako niepełnosprawny gracz, który jest w takiej sytuacji uzależniony od dobrej woli i pobłażliwości przyjaciół. Wolniejszy czas wykonywania zadań, niemożność uchwycenia wszystkich informacji graficznych są akceptowane łatwiej, niż bycie „innym” z uwagi na korzystanie $\mathrm{z}$ technologii wspomagających. W tym przypadku symbolika technologii wspomagających przewyższyła funkcjonalność i potrzebę użytkowania. Gdy ludzie postrzegają technologie wspomagające jako wskaźniki niepełnosprawności i gorszości - odrzucają je, zwłaszcza wtedy, gdy korzystanie $\mathrm{z}$ nich jest komuś narzucone. W sytuacji jednak, gdy korzystanie $\mathrm{z}$ nich jest wolnym wyborem danej osoby, pozostawiają sobie opcję użycia technologii w różnych okolicznościach. Wynika z tego, że aby uzyskać wysoki poziom użyteczności, 
technologie wspomagające muszą ograniczyć wysiłek fizyczny, poznawczy i językowy konsumentów, być komfortowe w użyciu, wydajne i produktywne, ale co ważniejsze, muszą wspierać pozytywny odbiór użytkownika w oczach znaczących bliskich mu osób. Po raz kolejny należy więc stwierdzić, że użyteczność nie jest wyłączną cechą technologii wspomagających, jednoznacznie determinującą ich wybór. Równie istotne jest uznanie interakcji człowiek-urządzenie-środowisko (Arthanat $i$ in. 2007).

Inaczej sytuacja przedstawia się w grupie osób niewidomych. Informacyjnokomunikacyjne technologie wspomagające włączają jednostki niewidzące do środowiska widzących oraz pozwalają tworzyć sieci kontaktów (np. przez internet). Koszty społeczne oceniane są inaczej. Słabowidzący bardziej niż niewidomi odczuwają, że technologie wspomagające zwracają uwagę na ich niepełnosprawność.

\section{Podsumowanie}

Podsumowując analizę danych empirycznych, pozyskanych w różnych warunkach społeczno-ekonomiczno-kulturowych, warto zwrócić uwagę, iż w tych przestrzeniach, w których dostęp do technologii wspomagających jest łatwiejszy (np. w krajach skandynawskich, narzędzia udostępniane są użytkownikom bezpłatnie po spełnieniu pewnych warunków), w badaniach eksponowane są aspekty społeczne związane z użytkowaniem technologii. Z kolei w badaniach amerykańskich i brytyjskich nacisk położony jest na efektywność korzystania z narzędzi w edukacji. $\mathrm{W}$ warunkach polskich, tak na płaszczyźnie teoretyczno-empirycznej, jak i praktycznej, widoczna jest koncentracja na kwestii niwelowania barier w dostępie do specjalistycznego sprzętu i oprogramowania. Preferencje polskich użytkowników w zakresie wyboru technologii słuchowych są wyzwaniem dla edukacji.

Nie ulega bowiem wątpliwości, że użytkowanie informacyjno-komunikacyjnych technologii wspomagających przez osoby z dysfunkcją wzroku we współczesnym, zaawansowanym technologicznie świecie, jest niezbędne dla zwiększenia ich samodzielności, sprawności w zakresie wykonywania codziennych zadań, dostępu do informacji, zwiększenia własnych kompetencji i kwalifikacji zawodowych, a preferencje użytkowników, dotyczące wyboru określonych narzędzi, są zwrotnie powiązane z zakresem ich doświadczeń w obszarze wykorzystania technologii. Dlatego niezbędne jest:

- nabycie przez osoby z dysfunkcją wzroku umiejętności posługiwania się technologiami wspomagającymi. Na etapie szkolnym przede wszystkim ważny jest dostęp do sprzętu i oprogramowania (różnorodnego). Osoby muszą mieć styczność z wieloma narzędziami wspomagającymi, żeby później mogły wybierać je w zróżnicowanych sytuacjach;

- wykorzystywanie multimodalnego sprzętu i oprogramowania - nieograniczanie technologii tylko do jednego kanału poznawczego (słuchu, dotyku); 
- wsparcie osób niepełnosprawnych wzrokowo ze strony nauczycieli. Kompetencje pedagogów w zakresie doboru sprzętu i metodyki nauczania są kluczowe. Nie wystarczy tylko wiedza o działaniu danego narzędzia, ale potrzebna jest praktyczna umiejętność przekazania instrukcji użytkowania danego urządzenia oraz projektowania sytuacji dydaktycznych umożliwiających wykorzystanie tego sprzętu. Kompetentny nauczyciel powinien zdawać sobie sprawę z wagi systemu brajlowskiego w edukacji osób niewidomych i propagować komplementarne technologie wspomagające, łączące systemy słuchowe i dotykowe (system Braille’a), ogólnodostępne i wyspecjalizowane;

- wykorzystywanie i łączenie ze sobą na etapie wczesnej edukacji różnych technologii i strategii nauczania w oparciu o narzędzia wspomagające;

- uwzględnianie w procesie doradztwa czynników społecznych, istotnych dla użytkowników.

\section{Bibliografia}

Arthanat S. i in. (2007). Conceptualization and measurement of assistive technology usability. „Disability and Rehabilitation: Assistive Technology 2”, nr 4.

Bickford J. O., Falco R. A. (2012). Technology for early Braille literacy: Comparison of traditional Braille instruction and instruction with an electronic notetaker. "Journal of Visual Impairment \& Blindness", nr 106.

Burda M., Wyplosz C. (200o). Makroekonomia. Podręcznik europejski (wyd. II zmienione), Warszawa: Polskie Wydawnictwo Ekonomiczne.

Chan S., Foss B., Poisner D. (2009). Assistive technology for reading. „Intel ${ }^{\circ}$ Technology Journal", nr 3.

Cryer H., Home S. (2011). Use of braille displays. Research report 15. RNIB Centre for Accessible Information: Birmingham.

D'Andrea M. F. (2012). Preferences and practices among students who read Braille and use assistive technology. „Journal of Visual Impairment and Blindness", nr 106.

Emiliani P. L. (2006). Assistive technology (AT) versus mainstream technology (MST): The research perspective. „Technology and Disability”, $\mathrm{nr} 18$.

Ferrell K. A., Bruce S., Luckner J. L. (2014). Evidence-based practices for students with sensory impairments (Document No. IC-4). University of Florida, Collaboration for Effective Educator, Development, Accountability, and Reform Center, dostępny na: http://ceedar.education.ufl.edu/tools/innovation-configurations (otwarty: 22 grudnia 2016 roku).

Kilian M., Śmiechowska-Petrovskij E. (2015). Bezwzrokowe odczytywanie drukuimplementacja narzędzia RoboBraille na grunt polski. „Niepełnosprawność i Rehabilitacja", $\mathrm{nr} 2$.

Łukowski W. (red.) (2008). Osoby z ograniczona sprawnością na rynku pracy-portret środowiska. Warszawa: Academica. 
Ravneberg B. (2009). Identity politics by design - users, markets and the public service provision for assistive technology in Norway. „Scandinavian Journal of Disability Research", 11 (2).

Rubin M., Faderewski M., Mikułowski D. (2015). Badania stanu i potrzeb informatyzacji edukacji matematycznej uczniów niewidomych i słabowidzących w Polsce. „E-mentor”, 1 (58).

Shimomura Y., Hvannberg E., Hafsteinsson H. (2010). Accessibility of audio and tactile interfaces for young blind people performing everyday tasks. „Universal Access in the Information Society", nr 9 (4).

Shinohara K., Tenenberg J. (2009). A blind person's interactions with technology. „Communications of the ACM”, nr 8.

Sobol E. (red.) (2002). Nowy słownik języka polskiego. Warszawa: PWN.

Söderström S., Ytterhus B. (2010). The use and non-use of assistive technologies from the world of information and communication technology by visually impaired young people: a walk on the tightrope of peer inclusion. „Disability \& Society”, nr 3.

Śmiechowska-Petrovskij E. (2016). Integrowanie technologii i technik brajlowskich w edukacji uczniów z niepełnosprawnościa wzroku. W: Paplińska M. (red.). Pismo Braille'a. Z tradycja w nowoczesność. Warszawa: Fundacja Polskich Niewidomych „Trakt”.

Varian H. R. (2005). Mikroekonomia. Kurs średni-ujęcie nowoczesne. Warszawa: PWN.

Walter N. (2007). Nowe media dla niewidomych i słabowidzących. Poznań: Wydawnictwo UAM.

Wielandt T., McKenna K., Tooth L., Strong J. (2006). Factors that predict the postdischarge use of recommended assistive technology $(A T)$. „Disability \& Rehabilitation: Assistive Technology", nr 1 (1-2).

Zawadzka Z. (2002). Podstawy teorii zachowań konsumenta. W: S. Marciniak, Makro- i mikroekonomia. Podstawowe problemy. Warszawa: PWN.

\title{
BLIND AND VISUALLY IMPAIRED PEOPLE'S PREFERENCES IN CHOOSING ASSISTIVE TECHNOLOGY
}

\begin{abstract}
The article discusses the issue of blind and visually impaired people's preferences in choosing assistive technology. Assistive technology is an important tool for them as it helps in the process of education, communication and mobility by compensating the lack of visual information. The article, which is based on a research, shows possibilities and barriers of using AT by people with vision problems and places a special emphasis on the social factors determining preferences in choosing hardware and software. Review and analysis of empirical data allowes to formulate important conclusions for the practice of education and rehabilitation of the blind and visually impaired people.
\end{abstract}


Keywords: preferences, blindness, visual impairment, assistive technology, Braille system, social factors.

Emilia Śmiechowska-Petrovskij - doktor nauk społecznych w dyscyplinie pedagogika, pedagog specjalny (tyflopedagog) i filolog polski, adiunkt w Katedrze Pedagogiki Specjalnej Przedszkolnej i Wczesnoszkolnej Wydziału Nauk Pedagogicznych Uniwersytetu Kardynała Stefana Wyszyńskiego w Warszawie, ekspert Ośrodka Rozwoju Edukacji ds. weryfikacji podręczników i książek pomocniczych w brajlu i powiększonym druku, rzeczoznawca MEN ds. podręczników dla dzieci o specjalnych potrzebach edukacyjnych. Zainteresowania badawcze: wsparcie osób z niepełnosprawnościami, ze szczególnym uwzględnieniem niepełnosprawności wzrokowej, w obszarze edukacji, integracji społecznej i uprzystępnianie dóbr kultury. Autorka ponad 30 opracowań naukowych i popularnonaukowych z obszaru tyflopedagogiki. Pozycje książkowe: Książki literackie dla niewidomych dzieci w młodszym wieku szkolnym. Perspektywa dorosłych pośredników (Warszawa 2017), K. Krawiecka, E. Śmiechowska-Petrovskij, M. Żelazkowska, Sztuka/twórczość dostępna. Osoby z niepetnosprawnościami i chorobą psychiczną $w$ kręgu recepcji i ekspresji sztuki (Warszawa 2016), redaktorka i współredaktorka książek: Dzieci z trudnościami adaptacyjnymi w młodszym wieku. Aspekty rozwojowe i edukacyjne w kontekście specyfiki różnic kulturowych (Warszawa 2016), Selected Aspects of Psychosocial Functioning of Persons with Disabilities (Warszawa 2016), Krawiecka K., Śmiechowska-Petrovskij E., Tempczyk-Nagórka Ż. (red.). Adres do korespondencji: Wydział Nauk Pedagogicznych, ul Wóycickiego 1/3, 01-938 Warszawa. Adres e-mailowy: e.smiechowska@uksw.edu.pl. 